\title{
Flood risk management, an approach to managing cross- border hazards
}

\author{
L. J. Bracken ${ }^{1}$ E. A. Oughton ${ }^{2}$ A. Donaldson ${ }^{3}$. \\ B. $\operatorname{Cook}^{4} \cdot$ J. Forrester ${ }^{5}$ - C. Spray $^{6} \cdot$ S. Cinderby ${ }^{7}$. \\ D. Passmore $^{8} \cdot$ N. Bissett 9
}

Received: 16 March 2015/Accepted: 3 March 2016/Published online: 11 April 2016

(C) The Author(s) 2016. This article is published with open access at Springerlink.com

\begin{abstract}
River flooding is a serious hazard in the UK with interest driven by recent widespread events. This paper reviews different approaches to flood risk management and the borders (physical, conceptual and organisational) that are involved. The paper showcases a multi-method approach to negotiating flood risk management interventions. We address three fundamental issues around flood risk management: differences and similarities between a variety of approaches; how different approaches work across borders between professionals, lay people, organisations and between different planning regimes; and, whether the science evidence base is adequate to support different types of flood risk management. We explore these issues through a case study on the River Tweed using Q methodology, community mapping and focus groups, participatory GIS, and interviews, which enabled co-production of knowledge around possible interventions to manage flooding. Our research demonstrated that excellent networks of practice exist to make
\end{abstract}

\section{J. Bracken}

1.j.bracken@durham.ac.uk

1 Department of Geography, Durham University, Durham DH1 3LE, UK

2 Centre for Rural Economy, Agriculture Food and Rural Development, Newcastle University, Newcastle NE1 7RU, UK

3 School of Architecture, Planning and Landscape, Claremont Tower, Newcastle University, Newcastle NE1 7RU, UK

4 Department of Resource Management and Geography, University of Melbourne, Parkville, VIC, Australia

5 York Centre for Complex Systems Analysis, Ron Cooke Hub, University of York, York YO10 5DD, UK

6 UNESCO Centre for Water Law, Policy and Science, Peters Building, University of Dundee, Dundee DD1 4HN, Scotland, UK

7 Stockholm Environment Institute, Grimston House, University of York, York, UK

8 School of Geography, Politics and Sociology, Newcastle University, Newcastle NE1 7RU, UK

9 Tweed Forum, South Court, Dryrange Steading, Melrose, Roxburghshire TD6 9DJ, UK 
decisions about flood risk management in the Scottish-English borders. Physical and organisational borders were continually traversed in practice. There was an overwhelming desire from professional flood managers and local communities for an alternative to simply structural methods of flood management. People were keen to make use of the ability of catchments to store water, even if land needed to be sacrificed to do so. There was no difference in the desire to embrace natural flood management approaches between people with different roles in flood management, expertise, training or based in different locations. Thus conceptual borders were also crossed effectively in practice.

Keywords Flooding $\cdot$ Natural flood management $\cdot$ Adaptive flood management

\section{Introduction}

River flooding is a serious hazard in the UK with nearly five million people, two million homes and businesses and assets worth $£ 250$ billion estimated to be at risk in England and Wales (FORESIGHT 2004; Wilby et al. 2008). A further 125,000 properties are at risk of flooding in Scotland, with an associated average annual cost of between $£ 720$ million and $£ 850$ million (SAIFF 2011). Flooding in the winter of 2015-2016 was again a high-profile issue as homes were inundated and at least 40 bridges damaged or destroyed, impacting local people and businesses. Debate around flooding in the UK is rife; Hannaford and Marsh (2006) and Pattison and Lane (2012) suggested that fluvial flooding is increasing, yet others have suggested otherwise (Disse and Engel 2001; Robson 2002; Marsh and Harvey 2012). Future changes to climate are also uncertain, with more extremes of climate expected (Kendon et al. 2014). Recent studies have also called for more integration between researchers, policy makers, and practitioners to interact to identify research and professional priorities (Brown et al. 2010; Lane et al. 2011). It has been advised that even to just maintain current standards of flood protection it will cost over $£ 1$ billion per year by 2035 (National Audit Office 2014). Flood risk management (FRM) professionals are also under pressure from the UK Government to champion protection of homes over environmental sustainability. Uncertainty thus exists over people's understanding of flooding, the uptake of flood prevention measures, but also the ways in which to most effectively manage flood water.

According to UNISDR (2013) governments are investing more to address risks by making substantial progress in developing more effective disaster response and preparedness strategies. Yet the required shift necessary to anticipate risks in public and private investment remains a challenge (UNISDR 2013); this is especially pertinent for FRM. FRM is complex, and this complexity risks hampering sustainable water management (Pitt 2008; Brown et al. 2010). In recent years, there have been dramatic changes in regulation and practices of managing flooding in the UK (Lane et al. 2013). The primary pieces of legislation that provide the drivers for flood risk management in England and Scotland are the Flood and Water Management Act (2010) and the Flood Risk Management Act (Scotland) 2009. These were supplemented by the Water Act (2014) which outlined the development of Flood Re (Flood Reinsure), a government insurance industry cross-subsidy scheme to maintain insurability of high flood risk homes. The latest act thus adds Flood Re to the list of potential measures for managing flood risk. With such developments in risk management and flooding, it is vital to understand the practice of flood risk management in the UK. Many 
different studies of flood risk management exist in both academic and grey literatures, but concepts and approaches are rarely brought together to compare and contrast different ways of working and to evaluate practice. Where there seems to be a particular gap is in understanding why different approaches to flood management are used and how these are routinely employed across the many different types of border involved in flood risk management (physical, conceptual and organisational).

It has been demonstrated that the biggest issue for stakeholders within the water sector in the UK is the need to understand the impacts of catchment management interventions on

Table 1 Overarching approaches to managing the natural environment

\begin{tabular}{|c|c|c|c|}
\hline $\begin{array}{l}\text { Environmental } \\
\text { management } \\
\text { framework }\end{array}$ & Description & Frameworks developed & Relationship to borders \\
\hline $\begin{array}{l}\text { Sustainable } \\
\text { environmental } \\
\text { management }\end{array}$ & $\begin{array}{l}\text { An overarching approach } \\
\text { for managing the } \\
\text { environment to meet the } \\
\text { needs of present } \\
\text { generations without } \\
\text { compromising the ability } \\
\text { of future generations to } \\
\text { achieve their needs } \\
\text { (Armitage and Pardo } \\
\text { 1995) }\end{array}$ & $\begin{array}{l}\text { 1. Ecosystem approach to } \\
\text { planning (Crombie 1991) } \\
\text { 2. The holistic resource } \\
\text { management model } \\
\text { (Savory and Savory } \\
\text { 1988) } \\
\text { 3. The agroecosytems } \\
\text { management approach } \\
\text { (Conway 1987) } \\
\text { 4. Integrated watershed } \\
\text { planning (Dixon and } \\
\text { Easter 1991) } \\
\text { 5. Social-ecological } \\
\text { systems (SES) (Ostrom } \\
\text { et al. 1994; Ostrom 2009) }\end{array}$ & $\begin{array}{l}\text { Only possible if the } \\
\text { ecological, socio- } \\
\text { economic and } \\
\text { institutional elements that } \\
\text { interact are effectively } \\
\text { integrated in the planning } \\
\text { management system } \\
\text { (Armitage and Pardo } \\
\text { 1995) } \\
\text { Crosses borders between } \\
\text { units of resource, but also } \\
\text { demands integration of } \\
\text { institutions and } \\
\text { organisations }\end{array}$ \\
\hline $\begin{array}{l}\text { Integrated } \\
\text { catchment } \\
\text { management }\end{array}$ & $\begin{array}{l}\text { A specific approach to } \\
\text { sustainable } \\
\text { environmental } \\
\text { management that } \\
\text { recognises that the } \\
\text { natural processes in a } \\
\text { catchment are connected } \\
\text { through the hydrological } \\
\text { cycle } \\
\text { Promoted by recent } \\
\text { legislation including the } \\
\text { EU Water Framework } \\
\text { Directive (WFD) (EC } \\
\text { 2000, 2003; Holzkämper } \\
\text { et al. 2012; Cook and } \\
\text { Spray 2012) }\end{array}$ & $\begin{array}{l}\text { 1. Ecosystem Services } \\
\text { Approach to land use and } \\
\text { resource planning and } \\
\text { management (Cook and } \\
\text { Spray 2012) } \\
\text { 2. The participatory } \\
\text { planning approach has } \\
\text { been recommended to } \\
\text { facilitate knowledge } \\
\text { exchange, structure the } \\
\text { management problem, } \\
\text { and negotiate } \\
\text { management scenarios } \\
\text { that carry the greatest } \\
\text { level of support amongst } \\
\text { the affected parties } \\
\text { (Westmacott 2001; } \\
\text { Carter and Howe 2006; } \\
\text { Holzkämper et al. 2012) }\end{array}$ & $\begin{array}{l}\text { Different management } \\
\text { perspectives: intervention } \\
\text { with respect to one } \\
\text { objective (e.g. flood } \\
\text { protection) is likely to } \\
\text { impact on other } \\
\text { management objectives } \\
\text { (e.g. the ecological status } \\
\text { of a river) } \\
\text { Crosses different domains } \\
\text { relevant to the river } \\
\text { catchment including river } \\
\text { processes, biodiversity, } \\
\text { policy, culture and ethics } \\
\text { (Acreman 2001; De } \\
\text { Nooij et al. 2004; } \\
\text { Straatsma and Baptists } \\
\text { 2008; Straatsma and de } \\
\text { Nooij 2010) } \\
\text { Cuts across different } \\
\text { disciplines and affects the } \\
\text { interests of many } \\
\text { different stakeholders- } \\
\text { especially between } \\
\text { decision makers and } \\
\text { communities }\end{array}$ \\
\hline
\end{tabular}


the water environment, especially flooding (Brown et al. 2010). We suggest that before it is possible to understand the impacts of management on the water environment, we should determine how management decisions are made in practice. The purpose of this paper is therefore to review the different approaches to flood risk management, how these cross a multitude of different borders (physical, conceptual and organisational) and to showcase a multi-method approach to negotiating flood risk management interventions. The research presented explores practitioner and professional approaches to flooding, views of local communities and how people with local expertise wish to see flooding managed. This is the first time that these questions have been brought together and synthesised around flooding. The findings develop a new way of interrogating knowledge around flooding and enable insights into how decisions are made in practice. We note that border studies is a subject in itself that explores geopolitics and border control (e.g. Newman 2006). In our evaluation of FRM we are concerned with the different types of borders involved in decision-making in practice and therefore do not reference this body of work.

\section{Flood risk management and the importance of borders}

\subsection{Approaches to flood risk management (FRM)}

Before we examine the different types of borders in flood risk management, it is important to understand the context in which they have evolved. Flood risk management is one aspect of integrated catchment management, which is in turn one element of sustainable environmental management. Table 1 outlines the range of approaches to environmental management and Table 2 the different approaches to FRM.

Tables 1 and 2 highlight the varied ways in which environmental management is portrayed and the different ways of working that are undertaken. There are many overlapping and related ways in which both environmental management and flood risk are framed, with related uncertainties. For example natural flood management (NFM) is sometimes characterised as uncertain because it lacks a 'sufficient' scientific evidence base (O'Connell et al. 2007; Marshall et al. 2009; Hess et al. 2010). The majority of scientific analyses of NFM explore the question of whether upland land management can affect river flow in order to attenuate flood peaks (Lane et al. 2006; McCormick et al. 2009). Some studies, such as Nicholson et al. (2012) in the Belford catchment and Werritty et al. (2010) in the Eddleston Water catchment, have investigated the impact of runoff attenuation features on flood flow, but there are not yet enough results to determine the full impact of these features. Hence there is little scientific evidence of the long-term catchment wide efficacy of NFM except at a very small scale (Parrot et al. 2009; EA 2009). This discussion highlights the different perspectives of FRM and the borders that exist between conceptual approaches to environmental management. These are likely to map onto different trainings, experience and organisational priorities.

\subsection{The role of borders in flood risk management (FRM)}

Tables 1 and 2 outline some of the types of borders that are involved in FRM. In this article we characterise borders as physical, conceptual and organisational. These boundaries are arbitrary, current, fluid and porous (Bracken and Oughton 2014); how they function in practice influences the ways in which flood risk management is delivered in the UK. For 
Table 2 Approaches to flood risk management

\begin{tabular}{|c|c|c|c|}
\hline $\begin{array}{l}\text { Type of } \\
\text { FRM }\end{array}$ & Description & Key principles & Relationship to borders \\
\hline $\begin{array}{l}\text { Structural } \\
\text { FRM }\end{array}$ & $\begin{array}{l}\text { Interventions constructed } \\
\text { within a catchment to try to } \\
\text { protect areas from flooding } \\
\text { (Wescoat and White 2003) } \\
\text { Synonymous with river } \\
\text { control (Tobin 1995) }\end{array}$ & $\begin{array}{l}\text { 1. Includes 'hard- } \\
\text { engineering' solutions } \\
\text { embracing structures such } \\
\text { as flood banks, levees, } \\
\text { reservoirs, drainage ways } \\
\text { and dams } \\
\text { 2. Transfers flood risk from } \\
\text { one location to another }\end{array}$ & $\begin{array}{l}\text { Integrates knowledge of } \\
\text { flood areas with build } \\
\text { infrastructure } \\
\text { Crosses borders of different } \\
\text { expertise } \\
\text { Shifts responsibility for flood } \\
\text { damages from individuals } \\
\text { to the state and in so doing } \\
\text { can lead to subsidy (Tobin } \\
\text { 1995) }\end{array}$ \\
\hline $\begin{array}{l}\text { Sustainable } \\
\text { FRM }\end{array}$ & $\begin{array}{l}\text { Provides the maximum } \\
\text { possible social and } \\
\text { economic resilience } \\
\text { against flooding, by } \\
\text { protecting and working } \\
\text { with the environment, in a } \\
\text { way which is fair and } \\
\text { affordable both now and in } \\
\text { the future Werritty (2006) }\end{array}$ & $\begin{array}{l}\text { 1. Exchanges control of } \\
\text { rivers (except in densely } \\
\text { populated or economically } \\
\text { valuable contexts) for } \\
\text { human adjustments to } \\
\text { flooding and encourages } \\
\text { more ecologically } \\
\text { sustainable human- } \\
\text { environment relations } \\
\text { (Lane et al. 2011) } \\
\text { 2. Examples include } \\
\text { managing flood plains and } \\
\text { restoring wetlands } \\
\text { 3. Composed of different } \\
\text { tools which encompass } \\
\text { natural and adaptive flood } \\
\text { management }\end{array}$ & $\begin{array}{l}\text { Crosses organisations and } \\
\text { regulatory bodies (Pahl- } \\
\text { Wostl 2006) } \\
\text { Crosses professional and lay } \\
\text { knowledge } \\
\text { Well understood in theory } \\
\text { (see work by Newson and } \\
\text { Large 2006; Newson 2008; } \\
\text { McDonald et al. 2004), but } \\
\text { there is little evidence from } \\
\text { which to evaluate its } \\
\text { effectiveness }\end{array}$ \\
\hline $\begin{array}{r}\text { Natural } \\
\text { FRM }\end{array}$ & $\begin{array}{l}\text { A sub-field of SFM } \\
\text { Techniques that work with } \\
\text { natural hydrological and } \\
\text { morphological processes to } \\
\text { manage the sources and } \\
\text { pathways of flood waters } \\
\text { (SAIFF 2011) }\end{array}$ & $\begin{array}{l}\text { 1. Restoration, enhancement } \\
\text { and alteration of natural } \\
\text { features; excludes } \\
\text { traditional engineering that } \\
\text { disrupts natural processes } \\
\text { 2. Wetlands, woodlands and } \\
\text { floodplains are used to } \\
\text { retain floodwater and } \\
\text { reduce both the volume } \\
\text { and speed of delivery of } \\
\text { runoff } \\
\text { 3. Supports efforts to make } \\
\text { space for water or to live } \\
\text { with flooding (DEFRA, } \\
\text { 2005) }\end{array}$ & $\begin{array}{l}\text { Integrates valuing ecological } \\
\text { integrity, river health, } \\
\text { biodiversity, cultural } \\
\text { history, and landscape } \\
\text { values such as free } \\
\text { meandering rivers with } \\
\text { catchment management } \\
\text { (Straatsma and de Nooji } \\
\text { 2010) }\end{array}$ \\
\hline $\begin{array}{l}\text { Adaptive } \\
\text { FRM }\end{array}$ & $\begin{array}{l}\text { A systematic process that } \\
\text { learns from the outcomes } \\
\text { of operational programs, } \\
\text { but also feeds on expertise } \\
\text { and information, leading to } \\
\text { awareness, visualization } \\
\text { and acknowledgement of } \\
\text { implications (Clark 2002) }\end{array}$ & $\begin{array}{l}\text { 1. Involves continued } \\
\text { processes of social learning } \\
\text { (Pahl-Wostl et al. 2007) } \\
\text { 2. Enables informed and } \\
\text { aware stakeholder } \\
\text { participation } \\
\text { 3. NFM and/or SFM can be } \\
\text { applied as part of AFM }\end{array}$ & $\begin{array}{l}\text { Demands the integration and } \\
\text { communication between } \\
\text { organisations and } \\
\text { institutions involved in } \\
\text { FRM } \\
\text { Demands integration of } \\
\text { organisational and } \\
\text { institutional perspectives } \\
\text { with other stakeholders } \\
\text { including local } \\
\text { communities }\end{array}$ \\
\hline
\end{tabular}


instance at a national scale, there are marked differences reflecting both contrasts in legislation and also the way public bodies are organised to deliver flood risk management in England and Scotland. At a local level, contrasting views exist between engineers with technical knowledge and local residents with vernacular knowledge. Also at the local level are landowners reluctant to release land for natural flood management and urban residents at risk eager to embrace whatever is seen to work.

\subsubsection{Physical borders}

Physical borders consist of geographic boundaries of political entities or legal jurisdictions, such as between England and Scotland. Rivers themselves have long been used to denote political borders: the Rio Grande and the Colorado rivers constitute borders between Mexico and the USA; the Parana River between Argentina and Paraguay; and the Amazon between Peru and Colombia (Salman 2000). Borders may also be imposed on the physical landscape through human agency (Robinson 2012). Such borders exist at multiple scales: national, regional, county and town. These borders direct the way regulation for FRM is established and operationalised. For example, NFM is incorporated directly into Scottish policy (Scottish Executive 2009; Werritty and Chatterton 2004) and is a key part of efforts to implement more ecologically and economically sustainable flood management. However, in England, the rhetoric of NFM is encompassed in Government Strategy (e.g. in the Department of Environment, Food and Rural Affairs (DEFRA) strategy for 'Making Space for Water'), but it is not explicitly required.

Rivers also cross political borders leading to complex issues in governance and management (Sadoff and Grey 2002). Existing research has explored these challenges and has noted the importance of policy styles, especially the problematic transition from policy formulation to policy implementation in water management across jurisdictions (Kingsford 1999; Brochmann and Hensel 2009; Wiering and Arts 2006; Wiering et al. 2010). The spaces for management of rivers are thus fluid as they flow through particular locations; plants and animals may or may not move; and sediment and river materials flow or are deposited in particular places (Bracken and Oughton 2014).

2.2.1.1 Conceptual borders Conceptual borders encompass the approach and perspectives that shape FRM and the way management is enacted. Floods and their management tend to be interpreted in a specific way that is partly dictated by legislation, which is in turn related to a certain jurisdiction, which then informs and influences practice. Individuals and organisations themselves in turn interpret legislation and plans in different ways according to personal and local priorities (Bracken and Oughton 2013). There is a vast literature outlining different approaches to FRM, but also research that questions the prevailing interpretations of what flood management should be, how it should be assessed, and, therefore, how it should be practiced (Werritty 2006; Rouillard et al. 2015). Structural flood risk management (SFRM) is predicated on the physical control of rivers and their catchments and whilst it is the dominant form of flood management in much of the world, criticisms and alternatives are emerging, with the aim of sustainability prominent. Scotland is a notable hot spot of innovation in this regard (Holstead et al. 2015; Rouillard et al. 2015; Werritty 2006). 
2.2.1.2 Organisational borders Environmental management is one area of policy implementation that is both complex and dynamic requiring the engagement of a range of practitioners with overlapping and multiple objectives (Fish et al. 2010). Thus as well as physical and conceptual borders, FRM involves a wider range of managers and practitioners from a range of related and overlapping organisations. Each organisation has its own perspectives and priorities for management depending on their remit and objectives. A body of research has examined the engagement of a range of different stakeholders in the decision-making process concerned with the development and the implementation of environmental plans and practices (Callon 1999; Nowotny et al. 2001; Eden et al. 2006; Collins and Weinel 2011). In the area of land and water management, Juntti and Potter (2002), Medd and Marvin (2008) and Nutley et al. (2003) have focussed on practices of implementation. In his analysis of policy making, Hajer (2003) argued that in deliberating policy there is a simultaneous activity at play which involves the negotiation of new institutional rules, that is, the making and implementing of new rules at the same time. Understanding the negotiation and ways in which organisational borders play out in practice is thus central to this body of research.

One approach used to explore organisational boundaries is interpretive policy analysis (IPA); an analytic tool that recognises that there are at least three potential groups interpreting any policy: the policymakers themselves, those responsible for implementing the policy and those affected directly by the policy (Yanow 1996). Recognising expertise gleaned from a range of people thus becomes important, rather than relying on just one

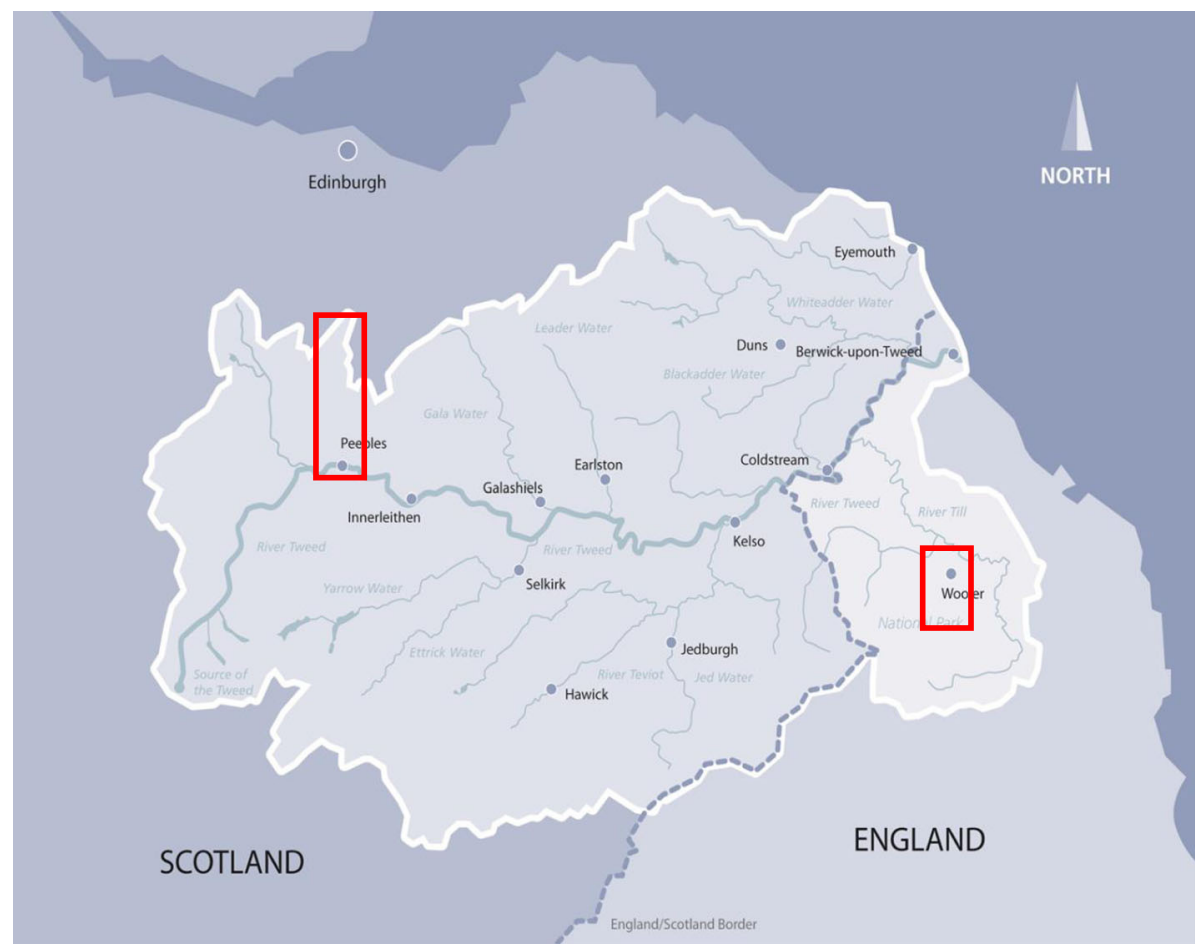

Fig. 1 Study area: the two boxes highlight the case study areas: The Eddleston that joins the River Tweed at Peebles and Wooler Water that joins the River Till in Wooler 


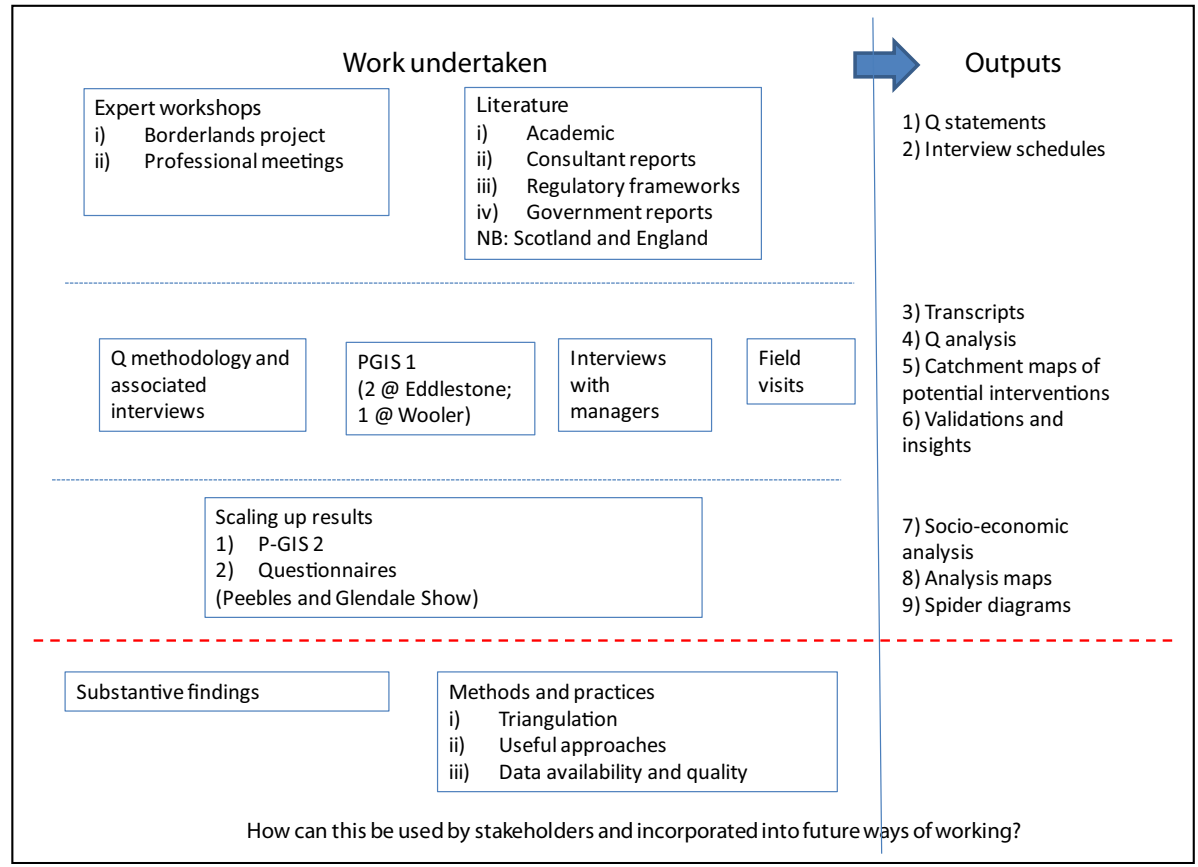

Fig. 2 Flow diagram of the research undertaken

expert. Jasanoff (2003) has raised numerous questions about what counts as relevant evidence with respect to a particular controversy and who possesses the right sort of knowledge to produce the evidence. Equally important is the mutual understanding between professionals with different bundles of expertise. This is closely related to the political culture of the decision-making process and the power relations between those involved (Bracken and Oughton 2013). As organisations involved in FRM cross physical, conceptual and organisational borders, they create new structures and practices that are central to delivering environmental management (Bracken and Oughton 2013).

2.2.1.3 Summary of borders in FRM FRM is complex and involves a range of types of borders that operate at different scales. Understanding FRM thus requires an analysis of not only regulation and policy guiding FRM, but also the knowledge claims that are able to persist (Callon 2004; Polasky et al. 2011; Whatmore 2002). Analysis of FRM regulation and policy has been undertaken (e.g. Lane et al. 2013), along with discussion of current debates that have arisen following recent flood events (Penning-Rowsell et al. 2014). However, none of these analyses include evaluation of the role of borders. As borders of landscape, jurisdiction, management approach and organisations are encompassed practice demands that different disciplines, trainings, understandings and technical languages are brought together. This adds to the complexity and difficulty of undertaking FRM in practice. 


\section{The managing borderlands project: overview and methodology}

The aim of the managing borderlands project was to understand and contribute to knowledge exchange between organisations and individuals concerned with flood risk management in towns and rural areas. Our research was focused on two sub-catchments of the River Tweed, which crosses the border between Scotland and England: Eddleston Water and Wooler Water (Fig. 1). There is a strong need to increase the flood resilience of the region in response to expected climate change which was underlined by severe flooding in the region in 2008 and 2009. The Tweed catchment thus provides an excellent case to illustrate the rapidly changing institutional environment that followed the floods of 2007 in England, the Pitt Review and consequent recommendations, the introduction of the Scotland Flood Risk Management Act 2009 and the Flood and Water Management Act 2010.

The way in which the research was undertaken is outlined in Fig. 2. At the outset of the research, we brought together a wide range of data (both quantitative and qualitative) that are used to inform management of flooding in borderlands across professional and lay organisations. We used these data to understand the interplay of regulation and practice and collect statements to be used in the Q methodology. We attended two meetings of professional flood managers: The New Civil Engineer Flood and Water Management Conference and the RELU-funded Catchment Management for Protection of Water Resources, both held in London in November 2010. These meetings brought together key individuals involved in flood risk management research and implementation in the UK and beyond. We then arranged two further 'expert' meetings, the first in January 2011 at the Flood Hazard Research Centre at Middlesex involving two senior flood researchers, and the second in March at the James Hutton Institute with six flood researchers.

Secondly we collected evidence on how actors refine the 'problem' of flooding from different perspectives, locales and experiences in order to ascertain possibilities for flood risk management and resilience building. To do this we used a combination of interviews, Q methodology and participatory mapping to collect data on how different groups explored and made decisions on flood management. A suite of approaches was used to better understand technical and locally popular implementation options for flood risk management and to explore which method was likely to capture and represent the range of diverse — and sometimes divergent—views amongst stakeholders (Forrester et al. 2015).

Semi-structured interviews were used as a suitable means through which to elicit views about the practice of, and stakeholder participation, in flood risk management. Fourteen interviews were conducted with the full range of representative of the flood risk management community, drawn from the EA, Scottish Environmental Protection Agency (SEPA), Scottish Government, Councils and NGOs identified in phase one of the research. Interviews followed a planned schedule and were recorded and transcribed. A thematic analysis of the transcripts was then conducted in which key phrases and ideas were identified and coded. Statements gathered from the interviews and transcriptions were added to the statement bank for the Q methodology.

Q Methodology is a research method used in psychology and social sciences to study people's "subjectivity" and is particularly useful when researchers wish to understand and describe the variety of viewpoints on an issue (Raadgever et al. 2008). Q methodology explores correlations between subjects across a sample of variables, reducing many individual viewpoints of the participants involved down to a few "factors," which are claimed to represent shared ways of thinking (Donaldson et al. 2010). The data for $Q$ factor analysis 
come from a series of "Q sorts" performed by participants. A $\mathrm{Q}$ sort is a ranking of variables, typically presented as statements. The sample of statements for a $\mathrm{Q}$ sort is drawn from the sum of all things people say or think about the issue being investigated. Participants are then given a grid and asked to order the statements on the grid, which forces participants to prioritise statements with a fine level of discrimination. Factor analysis and statistical analysis is then undertaken that provides an ideal arrangement of statements for each 'factor'. The ideal sort represents the view of a person who maps $100 \%$ on to the position at the core of the factor (participants will have a score indicating the extent to which their own sort maps onto this position). This ideal sort is then converted back into text that represents the key message through the interpretation of the researchers, looking at the statements that were at extreme positions on the grid and at the relative positions of statements.

We followed the process outlined by Donaldson et al. (2010). Initially the research team gathered over 2000 statements on the nature of flooding. These were then grouped and classified to produce 62 exclusive statements covering a wide range of opinions which were used in the Q sorts. For each Q sort, a group of people were brought together to represent a range of interests in flooding. Three meetings for the $\mathrm{Q}$ sorts were undertaken in April and May 2011: in Wooler, Eddleston and at the Tweed Forum in Melrose. The participants included policy, advisory and regulatory actors from England and Scotland, but also members of the local community to canvas the full range of stakeholders and views around FRM. In total $22 \mathrm{Q}$ sorts were obtained.

Participatory mapping was used in two ways. First, the maps were used to gather knowledge and ideas about flood risk and amelioration in the study area. Three community meetings were organised with local people in Wooler, Peebles and Eddleston. The maps used in each case covered the whole catchment at 1:15,000 and were combined with colour air photographs. Peebles town was enlarged to 1:10,000. The maps were cut at A0 size and acetates layered over them. Participants were asked to draw where flooding had occurred in the past on the first acetate. The second acetate was used to highlight where new flood protection or land use changes would help reduce flooding. The information from each map was then digitised into a GIS.

Secondly, the maps produced were validated with a wider constituency using Rapid Appraisal GIS (RAP-GIS). The digitised map for Eddleston Water was presented at the agricultural show in Peebles on August 13th 2011 and for Wooler Water at the Glendale show on 29 August 2011. Attendees were invited to comment on the maps and to make additional suggestions, using flags to mark locations and information. The participants were asked to choose one of the positions generated from the Q sort with which they identified most. In addition basic socio-economic data and post codes were collected from each participant in the exercise in order to determine whether buy-in came only from particular groups. A total of 60 questionnaires and mappings were collected in Peebles and 55 at Glendale. In this way both qualitative and quantitative data were used to generate understandings of the issues around flooding and flood management in each catchment. Data from the Q sort and RAP-GIS work were combined and analysed to provide a robust analysis of understanding of the problem of flooding and natural flood management.

We adopted a reflexive approach to labels such as 'local knowledge' and 'stakeholder' in this project, and have not drawn clear boundaries between categories of knowledge. Local knowledge contains not only the knowledge of local residents, but also that of scientists, academics, public servants and NGO workers who have a specialist interest in a particular locality. Here, the idea contrasts not with 'scientific' or 'expert' knowledge per 
se, but with top-down or 'off the peg' solutions. The sharing of 'local knowledge' is a key element to facilitating knowledge exchange.

\section{Crossing the borders of flood risk management}

\subsection{Sharing decision making between professionals in borderlands; crossing physical borders}

Mapping of the organisational linkages between actors and agencies showed them to be complex and dynamic. There were six key groups that met regularly whose remit covered flooding. These groups were composed of representatives from 17 organisations and different, but overlapping remits for environmental management; all encompassed FRM in some way. Significantly five people were common to all groups. This was highlighted in one interview:

....it's very incestuous, there are so few people down here that we all, all the same people go to the same meetings which may seem quite inefficient but in actual fact it allows for a lot more integration of what each delivers and so on and so we work on that basis. Flood Risk Practitioner 1

Hence the stakeholders themselves felt well connected and knew each other's roles and responsibilities well, despite multiple perspectives on how the groups and organisations came together to make decisions around flood risk management. The key individuals who were common to multiple groups involved in managing flood risk acted as both knowledge brokers and intermediaries. Social learning was perceived by stakeholders to be happening, and when we interviewed them in 2011, they had no desire for a new learning 'space' because they felt that data sharing was already happening between people within and between organisations.

Yet, during the research it emerged that whilst the communication and routes for knowledge exchange between professionals were well developed, there was still confusion about the practice of flood risk management, especially who was doing what where and how different organisations interpreted both regulation and uncertainty in knowledge and evidence. Figure 3 illustrates how the issue of flooding crosses different management plans for the River Tweed, which then relates to organisations in the borders in different ways. The Solway-Tweed River Basin Management Plan is a joint SEPA/EA statutory plan for delivering the EC Water Framework Directive, so it is not intended to operate as a frame for FRM. The actions are thus entirely framed within the context of the Tweed Catchment Management Plan. Flood risk management is only one of many objectives within the wider aspiration for integrated catchment management. However, implementation of the plan is necessary alongside the FRM (Scotland) Act. This serves to highlight the complexity of FRM in practice and how plans and actions between organisations overlap in practice. Some confusion was also the result of the pace in change of regulations, the time frame for consultation and the way on which such plans are published which then impacts on such conceptualisations of management. This is illustrated by one respondent as follows:

the sort of statutory deadlines that we've been set are very challenging, we've got a short time to do this work so we're having to use this first round of planning as a learning exercise Flood Risk Practitioner 2 




Fig. 3 How flood management was covered between management plans at the time of study in the River Tweed. Source Tweed Forum

The importance of networks and using trusted expertise was repeated in many interviews. Expertise was very much considered to be experiential. Respondents highlighted the importance of taking ideas from others within the regional network, more widely across the UK, and even recruiting individuals with certain experience to join organisations to strengthen local expertise.

I think it's often down to the individuals rather than any sort of leadership through organisations or any drive to make them joined up. Other people, will involve others they know because they know the contacts and they've had some history of working in partnership. Flood Risk Practitioner 3

Yet interviewees were also aware of the regulatory and governance structures within which they develop and implement catchment interventions. Changes in regulation were seen to encourage partnership working and underline the way in which organisations and individuals within these come together to make decisions.

... the framework of the new Flood Act actually requires people to work in partnerships and their argument would be that actually that's a much more mature way of getting a holistic answer to things.... Flood Risk Practitioner 4

Organisations may buy in and develop individual and group expertise, but this is not always communicated well, especially if the knowledge does not get picked up and transferred or used by the networks. Increasingly, this was compounded by the practice of 
outsourcing work and using consultants to undertake flood risk planning within responsible agencies.

\subsection{Professional views on sustainable flood risk management: blending conceptual borders}

Those responsible for regulation and implementation were caught between incompatible expectations rooted in changing approaches to flood risk management (sustainable versus structural). In addition, they face a mixture of external and internal pressures. On one side were factors such as new policies, research and public opinion, which are calling for a sustainable paradigm; on the other training, assumptions, methods, timescales and protocols, which supported existing knowledge and had validated previous expertise and behaviour. The prevailing interpretation of NFM was that it is a good but contested idea. A critical aspect of the 'challenge of NFM' is that it does not correspond with expectations amongst the flood risk management community. This was illustrated by one interviewee;

Somebody planting a forest somewhere up a tributary doesn't wash with them (the land owners) as the same level of defence or proof or scientific evidence or longevity or lots of other things and I think that's where the real problem is, when uncertain science collides with social, economic and human bits. Flood Risk Practitioner 6

While there are flood engineers and hydrologists developing tests to determine the effectiveness of NFM measures, the respondents each stated or alluded to distortions rooted in the social and political nature of support for NFM. They characterised NFM as a sociopolitical manifestation of the public's desire for a more natural system of flood management and associate NFM with 'popular' initiatives like river restoration. Support for SFM and NFM was thought to be somewhat idealistic due to its disconnection from an understanding of traditional flood risk management, meaning the physical nature and interactions between rivers and floodplains. There was also concern about how to widen decision making beyond just professionals representing certain organisations.

this new approach to flooding ... places quite a big emphasis on trying to take decisions jointly with people affected by the decisions and trying to do it as cooperatively as possible. The problem is the cost of doing that, it's not cheap.... And frankly the resources aren't there to do it properly and so you've got to take a step back from it. Flood Risk Practitioner 7

The respondents alluded to the uncertainty that surrounds NFM and its unlikely ability to control river behaviour. This uncertainty was rooted in a need for evidence and consistently forms the basis for scepticism. Many flood managers noted that although projects to assess the impact of NFM are in their infancy they are not seeing a lot of evidence that could really contribute significantly enough to the decision process at the moment. The required evidence needs to correspond with what is expected and what has traditionally fulfilled expectations. For example, despite having sufficient confidence to apply NFM, one respondent noted that he is also working with hydrologists to develop a more traditional evidence base for what he feels is proven flood risk management. This view alluded to the dominance of a scientific framing in the context of flood management and to the need for tangible evidence to determine 'what is effective'.

what is tending to influence flood policy is hard data and hard facts, reliable information on hazards and impact to people, businesses or kind of infrastructure so we 
have reliable data that we can build into the national assessment...., some of the softer information, anecdotal information is very difficult to build in at this point Flood Risk Practitioner 2

What did emerge from nearly every interview was the way in which SFM and NFM was being coupled with structural, hard-engineering approaches. Hence structural and NFM approaches were not an 'either/or' but rather were used in combination and based on both expertise and more traditional forms of data.

... we're looking at direct defences and we're looking at NFM, we are not looking at storage because [it] has been discounted through the flood study and even where conditions are favourable for storage.... They still don't stack up in cost-benefit terms because of the volumes of flow.... Flood Risk Practitioner 3

The combined use of approaches to flood risk management was repeated by all respondents but played out differently in each example discussed depending on site characteristics. One example discussed included 12-15 elements to the scheme rather than just one intervention. This included sections of flood bank within the town to stop the water getting in people's homes, additional pipes in the drainage system to add extra capacity and leaky ponds to hold water back in the side streams. Key issues that were repeatedly considered were the morphology of the site, the financial budget available to the scheme, the cost-benefit analysis of the proposed development and public opinion. Often NFM approaches were seen to be cheaper, partly because they were initiated at small scales with costs passed on to the land owner. Budgets (flood related and more widely) could also be used more flexibly to pay for small scale NFM interventions especially on the back of other catchment interventions. Yet it was also noted that due to the uncertainty around the effectiveness of NFM this was a risky way of working.

\subsection{The importance of specific sites; ways to integrate action across borders}

The role of the site was repeatedly mentioned in interviews with professional flood risk managers. Some comment was focused around the need for site-specificity when designing management interventions, which in turn led to problems in trying to develop large-scale, generic flood prevention schemes and passing on designs to other initiatives.

The local authority would traditionally take forward a river or a coastal flood protection scheme and would sort out the science behind it, the hydrology, hydraulic models, but as well they would consider all the aspects around developing a

Table 3 Significant statements that emerged from the Q methodology suggesting disagreement between participants

\begin{tabular}{lll}
\hline Statement & $\begin{array}{l}\text { Position 1 } \\
\text { rank }\end{array}$ & $\begin{array}{c}\text { Position 2 } \\
\text { rank }\end{array}$ \\
\hline $\begin{array}{l}\text { Traditional engineered flood defences are neither sustainable nor cost } \\
\text { effective }\end{array}$ & +5 & -5 \\
Some lands need to be sacrificed in the national interest & +4 & -5 \\
$\begin{array}{l}\text { No homes should be built on floodplains } \\
\text { Improved agricultural drainage leads to greater flood risk downstream }\end{array}$ & +2 & -3 \\
\hline
\end{tabular}


Table 4 Significant statements that emerged from the Q methodology suggesting agreement between participants

\begin{tabular}{|c|c|c|}
\hline Statement & $\begin{array}{l}\text { Factor } 1 \\
\text { rank }\end{array}$ & $\begin{array}{l}\text { Factor } 2 \\
\text { rank }\end{array}$ \\
\hline Existing and new developments in flood risk areas should be made flood resilient & +2 & +2 \\
\hline Flooding is only a problem because land use has changed & -3 & -3 \\
\hline $\begin{array}{l}\text { Sustainable flood management includes making good use of a catchment's natural } \\
\text { capacity to store water and reduce peak flows }\end{array}$ & +5 & +5 \\
\hline
\end{tabular}

scheme which would I start think to involve some of the more local information or local knowledge about the management of a particular river. Flood Risk Practitioner 6

There was a lack of clarity about where the jurisdiction of one organisation starts and ends in terms of managing flooding compared to another organisation (e.g. for instance main river versus tributaries), especially in England. Hence, partnership working at one particular location is an efficient way of bringing the full range of knowledge and expertise together to find out what other organisations are doing, be strategic about meeting multiple objectives, be strategic about developing match funding and securing support for a proposed intervention.

Analysis of the role and importance of particular sites led us to develop an understanding about how data and evidence tends to be used when making and designing flood

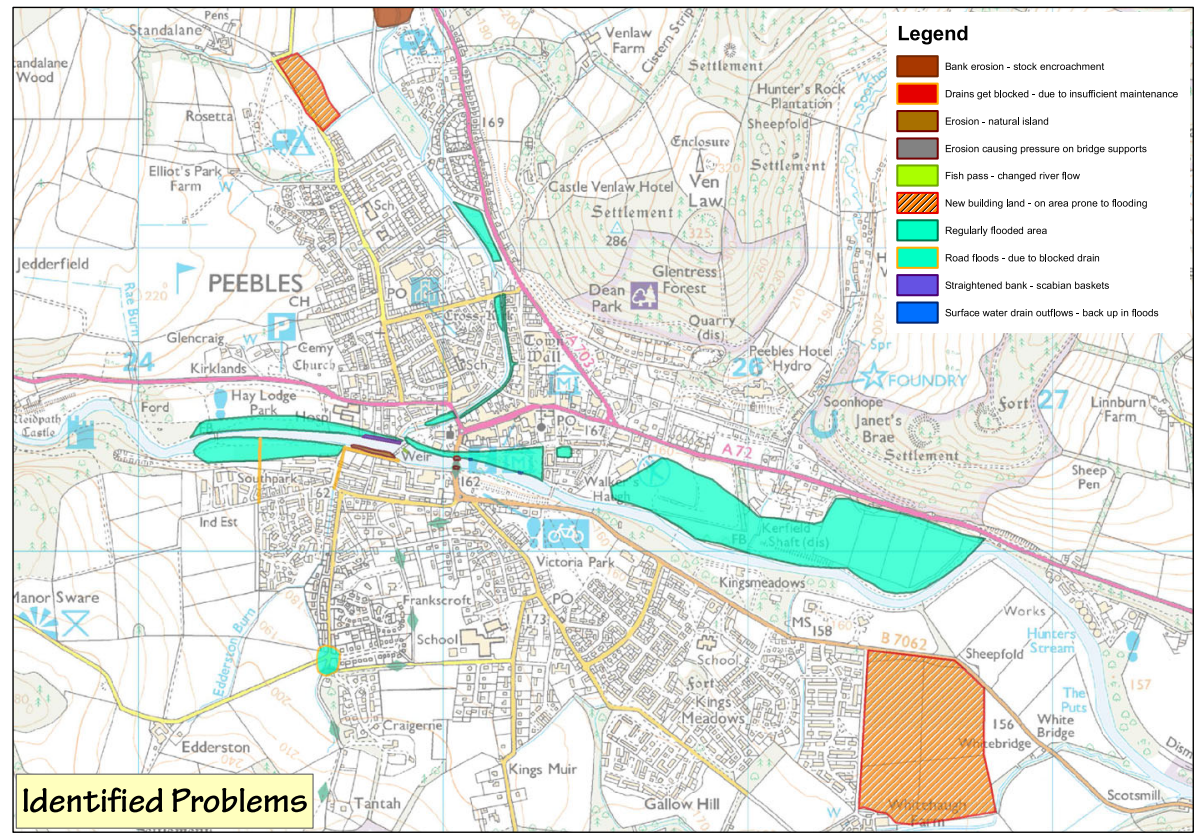

Fig. 4 Example map of digitised stakeholder comments in Peebles 
risk management interventions. The primary data (both physical and social) are collected and compiled by a range of actors from a range of sources. This knowledge is then spread around within organisations to make decisions within different sections of those organisations, for instance highways or flood management, or civil contingencies. The primary data were also used to produce a number of composite sources of information, such as flood risk maps, which are then used by multiple organisations in many different ways. As one interviewee noted:

We do hold a lot of national datasets with a lot of local detail on flood hazards and flooding in the past and we're generating new information to help inform this new kind of approach to flood management. Flood Risk Practitioner 1

Depending on the interpretation of regulation, the management objective in question and the funding available, the primary and composite data are brought to bear on a certain location. Around all the decisions, there are issues of quality and robustness of data, information and knowledge, and professionals tend to act on 'what is good enough' in terms of determining an intervention at a particular site. Thus the data, knowledge evidence, governance, practice and sociopolitical culture are entwined in managing flood interventions and can be crosscut at a particular location.

\subsection{Borders between different types of stakeholders}

Two discursive positions with respect to flood risk management emerged from the $\mathrm{Q}$ methodology. The four most significant statements that differentiated the positions are



Fig. 5 Example map of possible solutions to reduce flooding in Wooler 
listed in Table 3. Position 1 recognised a problem with traditional flood management, whereas position 2 did not. Position 1 considered the loss of land for flood protection to be justified, whereas position 2 thought this was unjustified. The first position was more sympathetic to preventing floodplain building than the second. Position 1 recognised the downstream risks posed by draining farmland, whereas position 2 was less concerned. We found no particular determining characteristics for why individuals ended up clustered on one view or the other, despite very different roles and knowledge (FRM professional versus community). Perspectives on the issue were not driven by differing policy or experience of flooding. The flipside of this was that the perspective of an individual cannot be assumed just by knowing their job or role, or where they live. The study also suggested that there was more agreement between participants than we anticipated (Table 4). Indeed there were three statements on which the positions were in agreement. Both were in agreement that natural storage is an important component of flood management. This agreement was slightly misleading since the statement ranked the same in both ideal sorts, but its absolute value was considerably more important in defining position 1 than position 2 .

These findings provided a more 'socially robust' basis for asking a wider constituency about the problem of flooding and potential solutions (i.e. it was not just the team's view being tested, but positions drawn from a range of different stakeholders). We constructed paragraphs representing the two positions found in the Q exercise. Three options were put to all respondents and they were asked to note which they most agreed with. Option 2 was derived from position 1 of the Q Methodology study; Option 1 and Option 3 were two differing interpretations of position 2. Option 1 focused on continuing to use engineering solutions; Option 3 was more concerned with building (social) resilience (Table 5). Results showed an overwhelming preference for Option 2 across all respondents (Table 6).

\subsection{Wider understandings of flood management in the borders}

Results in Sect. 4.4 were expanded by canvassing a greater number of people using participatory mapping. The general was that locally grounded stakeholders (both environmental professionals and others) can contribute usefully to problem definition and to option

Table 5 Options used for wider consultation

\begin{tabular}{|c|c|c|}
\hline Option 1 & Option 2 & Option 3 \\
\hline $\begin{array}{l}\text { Floods are such a big problem for } \\
\text { individuals and communities- } \\
\text { they leave emotional scars- } \\
\text { that we need to defend people } \\
\text { and properties with major } \\
\text { engineering works. No land } \\
\text { should have to be sacrificed to } \\
\text { prevent flooding elsewhere but } \\
\text { we can make use of a } \\
\text { catchment's natural capacity to } \\
\text { store water }\end{array}$ & $\begin{array}{l}\text { We need to look for alternatives } \\
\text { to traditional heavily engineered } \\
\text { flood defences-they aren't } \\
\text { sustainable economically or } \\
\text { environmentally. We should } \\
\text { make use of a landscape's } \\
\text { natural ability to store water. } \\
\text { The attitudes of farmers and } \\
\text { other land managers are a key } \\
\text { part of flood management. } \\
\text { Improving land drainage } \\
\text { upstream can lead to greater } \\
\text { flood risk downstream, so some } \\
\text { lands might have to be } \\
\text { sacrificed for flood protection }\end{array}$ & $\begin{array}{l}\text { Floods are really frightening and } \\
\text { leave emotional scars; } \\
\text { recovering from them can take } \\
\text { years. I don't really think about } \\
\text { flood defences (they might } \\
\text { never be enough); we need to } \\
\text { focus on people, helping them } \\
\text { prepare for floods }\end{array}$ \\
\hline
\end{tabular}


Table 6 Preference of options outlined in Table 5

\begin{tabular}{llll}
\hline Location & Option 1 & Option 2 & Option 3 \\
\hline Wooler & 4 & 39 & 5 \\
Peebles & 9 & 38 & 4 \\
\hline
\end{tabular}

generation with respect to flood risk management. Figure 4 shows the digitised version of one of the maps drawn by participants at the Peebles stakeholder mapping meeting (there are equivalent maps for Eddleston Water and Wooler Water). It shows their ideas of particular problem areas for flooding in the town. Using a map allowed stakeholders to agree amongst themselves to a high degree of accuracy where particular problems occur. This makes it useful to explain to technical experts what the local 'lay' knowledge actually is. Figure 4 was used as a base map within the local groups to initiate discussion about potential solutions: these were both (more natural) management measures upstream and more engineering-led solutions within the town itself (Fig. 5). The dichotomy between NFM as being perceived as something for the countryside and uplands, whereas more conventional engineering solutions are for the towns is highlighted in most of the maps. For example the Wooler participants mostly suggested NFM measures in upland areas but suggested-or offered for consideration-re-engineering the bridge in the town.

By using the maps and the Q outputs together in the RAP-GIS at the two shows, it was possible to get a feeling for the wider community uptake of the attitudes towards flood risk management and relate these to the scheme plans outlined on the maps. The findings were remarkably similar in Scotland (Peebles Show) and in England (Glendale Show at Wooler). The former had approximately $66 \%$ in favour of NFM-type solutions with $17 \%$ in favour of traditional 'engineering' solutions while another $17 \%$ either chose both or a mixture. In England (Glendale Show) the figures were $70 \%$ in favour of NFM $4 \%$ in favour of engineering solutions alone, and $26 \%$ choosing a mixed approach. These results show that the scheme preferences are closely linked to norms and values.

\section{Challenges in managing flooding across borders}

\subsection{Project approach}

The structured multi-method, multi-level approach adopted by the managing borderlands project: using Q methodology, community mapping and focus groups, participatory GIS and interviews enabled co-production of knowledge around possible interventions to manage flooding. However, each method retained an internal truth to the original data: maps are a good way to understand ideas for schemes, and Q methodology is a good way to understand values. The lesson of this experience is that no one method will suffice to unpick complex views and practices to engender better management across the strategic, decision-taking, and practical implementation stages. The approach enabled the full range of borders involved in FRM to be evaluated.

The capacity of Q Methodology to throw up surprising new points of view rests on the way in which perspectives raised by $\mathrm{Q}$ will not necessarily correspond to any individual participant's point of view. The Q outputs represent the viewpoint of an 'idealised' person who stands at the centre of a group of participants who all roughly agree on certain issues. All those who cluster around that idealised person have some common points of agreement that bring 
them together. One of the benefits of engaging in a $\mathrm{Q}$ sort is that it can force people to think hard about their point of view and prioritise their concerns. It can generate collective interest simply by virtue of being something different and encouraging self-reflection.

\subsection{The role of borders in flood risk management in practice}

Legislation, which informs conceptual borders, is constantly evolving making it difficult for professionals to develop and sustain practice: it is difficult to work out who is doing what where and when. Professional networks for managing floods in the Scottish-English borders are well established and work well in terms of generating personal connections and trust. Thus sharing expertise and knowledge across conceptual and organisational borders is undertaken effectively. However, there is ample opportunity for professionals to make more and sustained connections with local communities. Our research demonstrated that local communities are very knowledgeable about areas affected by flooding and potential management options. This finding agrees with other studies that have used different methods of co-producing knowledge about flooding (Lane et al. 2011, 2013). Often the conceptual approach was similar between different organisations and stakeholders. However, the borders present between professionals undertaking FRM and local communities could be traversed more effectively. This is illustrated by the finding that there was a feeling among people involved in the project (local communities and professionals) that there was a move among agencies from concern with the 1:200 or 1:100 year flood in rural areas to managing the smaller, more frequent floods that had high economic and social costs, and NFM was recognised as having a significant role to play in managing the risk of smaller events.

Results from the current investigation oppose a recent study by Harries and PenningRowsell (2011) on the River Thames that suggested structural methods continued to be used more frequently and effectively for flood risk management. Differences in results may be due to the way in which we used a range of methods to co-produce management solutions. Given that both Wooler Water and the Eddleston Water are sparsely populated rural catchments with low cost-benefit ratios, neither is likely to obtain large-scale flood defences in the short-to-medium term. This local context may have coloured the responses of participants in both the Q sort analysis and the interviews. Likewise structural measures are likely to have been privileged on the River Thames due to the training of the managers (most of whom were chartered engineers) and possibly due to the lack of confidence in non-structural measures in such a context.

Definitions exist for different types of flood management in the literature, but meanings and usage are not clearly delimited. In practice professionals from different organisations come together to manage water resources from many different perspectives (e.g. Bracken and Oughton 2013), and decisions around flood risk management are made in light of the most up to date regulations. However, regulations operate at a range of scales (EU, UK, regional) and are interpreted on the ground depending on the local catchment characteristics and the way in which organisations come together and prioritise work. Hence there is a process of communication and negotiation which takes place between and within relevant organisations. During this process definitions and understandings of approaches to flood management are rarely discussed. Instead management decisions focus at the practical level on use of specific tools and interventions that could be made. Our results suggest that in practice flood risk management schemes tend to combined approaches of structural, sustainable and natural flood risk management deemed appropriate to a site. Confusion also exists over whether NFM is a structural approach to flood risk management since it is constructed, albeit based on a different ideology than hard-engineering structures. Often 
researchers classify NFM as a non-structural measure since it involves working with rather than against nature. But the Scottish Government views any attempt to store water or slow down the flow as "structural" (including planting trees), and this is embedded in its guidance on appraisal. Thus NFM is a contested measure in terms of its classification, and our results demonstrate that the classification of tools and interventions used by flood managers and local communities do not necessarily neatly map onto the definitions of approaches to flood risk management outlined in Sect. 2.

The key aspect of the adaptive process is that it feeds on expertise and information that then leads to awareness, visualisation and acknowledgement of implications (Clark 2002). This role can only play out in practice if data sources, forms of knowledge and models are more expansive than those of conventional science-driven management (McLain and Lee 1996). Our results support previous research by Pahl-Wostl et al. (2007) that most flood risk management schemes tend to be developed using an adaptive approach involving routine dialogue and negotiation between institutions through highly integrated networks, but wider stakeholder engagement may be patchy. Professional flood managers do not label their practice as adaptive and undertake social learning amongst themselves to support their decision-making as a matter of course, rather than as anything unusual. The advent of requirements to involve stakeholders more through Local Flood Action and Advisory Groups set up to assist delivery of the EU Floods Directive may lead to further improvements enabling engagement with a wider set of knowledge. Our results demonstrate that inclusion of a wider group of stakeholders will contribute valuable knowledge and expertise and that they share a common vision for FRM with professional managers.

\subsection{Is there enough evidence to support interventions in practice?}

Our results demonstrated that there is an appetite within flood risk managers for more scientifically rigorous evidence around the effectiveness of natural and sustainable flood risk management at the whole catchment scale, as suggested by others (Parrot et al. 2009, Environment Agency 2009). Regulation is driving professionals more towards SFM and NFM; however, some are uncomfortable without measureable evidence to support the effectiveness of such tools. However, some flood managers have embraced NFM fully and apply it where possible. Environmental professionals involved in our research were happy to go with what's 'good enough' and make imperfect data work well for them. Professional environmental managers were highly skilled at making quick, efficient decisions based on limited evidence and with limited resources. What is lacking in current decision making around flood risk management is the view of local communities. Public engagement is high on the environmental management agenda and hence underlines the need for adaptive flood management. Open debate needs to be encouraged on the value of NFM to all households and businesses in rural catchments and to identify the distribution and magnitude of costs and benefits. Follow-up research is needed to evaluate the effectiveness of NFM and changing attitudes of households and communities.

\section{Conclusions}

It is a turbulent time in flood risk and land management. Being able to engage with a much wider set of tools and knowledge is becoming increasingly important. The research presented has showcased a multi-method approach to understand the practice of negotiating 
flood risk management interventions in the Scottish-English borders but also across physical, conceptual and organisational border. In so doing we have addressed three fundamental questions around flood management, namely the differences and similarities between approaches to flood management; how different approaches to flood management work across borders between professionals, lay people, organisations and between nations; and the quality of the science evidence base which underpins sustainable flood management. Our conclusions are:

1. Existing flood intervention schemes are composed of multiple approaches and tools including traditional (structural) approaches and SFM (including NFM and AFM). Multiple perspectives and tools are well understood by multiple organisations and individuals.

2. There was an overwhelming desire from professional flood managers and local communities for an alternative to simply structural methods of flood management. People were keen to make use of the ability of catchments to store water, even if land needed to be sacrificed to do so.

3. There was no difference in the desire to embrace NFM approaches to flood management between people with different roles in flood management, between various expertises, or with different trainings.

4. Local people who have no professional responsibility for flood management have excellent understandings of flooding including location, extent and duration and in turn have excellent ideas about possible management interventions to reduce risk, coupled with understanding of what may/may not be acceptable to the local community. This should be harnessed by flood risk managers.

5. Excellent networks of practice exist to make decisions about flood risk management in the Scottish-English borders.

6. A multi-method approach was an excellent way to capture how flood risk management works in practice in the Borderlands and how varied and wide ranging views and perspectives work in practice.

7. Q methodology and participatory mapping are potential methods that could be used by organisations to engage with more local knowledge and increase social learning as part of adaptive flood management.

8. More effort needs to be made to evaluate the effectiveness of NFM tools to reduce flooding. This may require data collection and modelling to be undertaken in more novel ways, different than traditionally undertaken.

Whilst a range of types of borders exist, understanding how they operate in practice has resulted in important findings that have implications for FRM. Inclusion of a broader group of stakeholders will only strengthen knowledge of flood risk and potential mitigation measures, not add a different dimension to conceptual understandings of FRM. The greater challenge is possibly educating governments and the media, to challenge their growing expectation that homes and business can be protected from flooding without sustaining catchments in a holistic manner.

Acknowledgments This paper has developed from RES-240-25-0020 funded by the ESRC led RELU programme, with additional funding from Scottish Government. We thank all those who took part in the study; their views and experience are central to the case study reported. We also thank two anonymous referees for their helpful comments which helped improve the paper.

Open Access This article is distributed under the terms of the Creative Commons Attribution 4.0 International License (http://creativecommons.org/licenses/by/4.0/), which permits unrestricted use, distribution, 
and reproduction in any medium, provided you give appropriate credit to the original author(s) and the source, provide a link to the Creative Commons license, and indicate if changes were made.

\section{References}

Acreman M (2001) Ethical aspects of water and ecosystems. Water Policy 3(3):257-265

Armitage PD, Pardo I (1995) Impact assessment of regulation at the reach level using macroinvertebrate information from mesohabitats. Regul Rivers: Res Manag 10(2-4):147-158

Bracken LJ, Oughton EA (2013) Making sense of policy implementation: the construction and uses of expertise and evidence in managing freshwater environments. Environ Sci Policy 30:10-18

Bracken LJ, Oughton E (2014) How to make sense of our rivers: using assemblage to understand angling. Wiley Interdiscip Rev: Water 1(3):315-322

Brochmann M, Hensel PR (2009) Peaceful management of international river claims. Int Negot 14(2):393-418

Brown LE, Mitchell G, Holden J, Folkard A, Wright N et al (2010) Priority water research questions as determined by UK practitioners and policy makers. Sci Total Environ 409:256-266

Callon M (1999) The role of lay people in the production and dissemination of scientific knowledge. Sci Technol Soc 4(1):81-94

Callon M (2004) The role of hybrid communities and socio-technical arrangements in the participatory design. J Centre Inf Stud 5(3):3-10

Carter J, Howe J (2006) Stakeholder participation and the water framework directive: the case of the Ribble Pilot. Local Environ 11(02):217-231

Clark MJ (2002) Dealing with uncertainty: adaptive approaches to sustainable river management. Aquatic Conserv: Mar Freshw Ecosyst 12(4):347-363

Collins H, Weinel M (2011) Transmuted expertise: how technical non-experts can assess experts and expertise. Argumentation 25(3):401-413

Conway GR (1987) The properties of agroecosystems. Agric Syst 24(2):95-117

Cook BR, Spray C (2012) Ecosystem services and integrated water resource management: Different paths to the same end? J Environ Manag 109:93-100

Crombie D (1991) Regeneration: Toronto's waterfront and the sustainable city Final Report Royal Commission of the Future of the Toronto Waterfront, Toronto

De Nooij RJW, Lenders HJR, Leuven RSEW, De Blust G, Geilen N, Goldschmidt B, Nienhuis PH (2004) BIO-SAFE: assessing the impact of physical reconstruction on protected and endangered species. River Res Appl 20(3):299-313

DEFRA (2005) Making space for water: First Government Response to the Autumn 2004 consultation exercise DEFRA

Disse M, Engel H (2001) Flood events in the Rhine basin: genesis, influences and mitigation. Nat Hazards 23(2-3):271-290

Dixon JA, Easter KW (1991) Integrated watershed management: an approach to resource management. In Dixon JA, Easter KW and Hufschmidt MM (eds) Watershed resources management: an integrated framework with studies from Asia and the Pacific, pp 3-15

Donaldson A, Ward N, Bradley S (2010) Mess among disciplines: interdisciplinarity in environmental research. Environ Plan A 42(7):1521

Eden S, Donaldson A, Walker GP (2006) Green groups and grey areas: scientific boundary work, NGOs and environmental knowledge. Environ Plann A 38(6):1061-1076

Environment Agency (2009) R\&D: update review of the impact of land use and management on flooding; delivery of making space for water: the role of land use and management

Fish RD, Ioris AA, Watson NM (2010) Integrating water and agricultural management: collaborative governance for a complex policy problem. Sci Total Environ 408(23):5623-5630

FORESIGHT (2004) Future Flooding Executive Summary Office of Science and Technology HMSO, London

Forrester J, Cook B, Bracken L, Cinderby S, Donaldson A (2015) Combining participatory mapping with Q-methodology to map stakeholder perceptions of complex environmental problems. Appl Geogr 56:199-208

Hajer M (2003) Policy without polity? Policy analysis and the institutional void. Policy Sci 36(2):175-195

Hannaford J, Marsh T (2006) An assessment of trends in UK runoff and low flows using a network of undisturbed catchments. Int J Climatol 26(9):1237-1253 
Harries T, Penning-Rowsell E (2011) Victim pressure, institutional inertia and climate change adaptation: the case of flood risk. Glob Environ Change 21(1):188-197

Hess TM, Holman IP, Rose SC, Rosolova Z, Parrott A (2010) Estimating the impact of rural land management changes on catchment runoff generation in England and Wales. Hydrol Process 24(10):1357-1368

Holstead KL, Kenyon W, Rouillard JJ, Hopkins J, Galán-Díaz C (2015) Natural flood management from the farmer's perspective: criteria that affect uptake. J Flood Risk Manag. doi:10.1111/jfr3.12129

Holzkämper A, Kumar V, Surridge BW, Paetzold A, Lerner DN (2012) Bringing diverse knowledge sources together-A meta-model for supporting integrated catchment management. J Environ Manag 96(1):116-127

Jasanoff S (2003) Breaking the waves in science studies: comment on Collins and Evans 'the third wave of science studies'. Soc Stud Sci 33(3):389-400

Juntti M, Potter C (2002) Interpreting and reinterpreting agri-environmental policy: communication, trust and knowledge in the implementation process. Sociologia Ruralis 42(3):215-232

Kendon EJ, Roberts NM, Fowler HJ, Roberts MJ, Chan SC, Senior CA (2014) Heavier summer downpours with climate change revealed by weather forecast resolution model. Nat Clim Change. doi:10.1038/ nclimate 2258

Kingsford RT (1999) Managing the water of the Border Rivers in Australia: irrigation, government and the wetland environment. Wetl Ecol Manag 7(1-2):25-35

Lane SN, Brookes CJ, Heathwaite LA, Reaney S (2006) Surveillant science: challenges for the management of rural environments emerging from the new generation diffuse pollution models. J Agric Econ 57(2):239-257

Lane SN, Odoni N, Landström C, Whatmore SJ, Ward N, Bradley S (2011) Doing flood risk science differently: an experiment in radical scientific method. Trans Inst Br Geogr 36(1):15-36

Lane SN, November V, Landstrom C, Whatmore S (2013) Explaining rapid transitions in the practice of flood management. Ann As Am Geogr 103(2):330-342

Marsh T, Harvey CL (2012) The Thames flood series: a lack of trend in flood magnitude and a decline in maximum levels. Hydrol Res 43(3):203-214

Marshall MR, Francis OJ, Frogbrook ZL, Jackson BM, McIntyre N, Reynolds B, Chell J et al (2009) The impact of upland land management on flooding: results from an improved pasture hillslope. Hydrol Process 23(3):464-475

McCormick BC, Eshleman KN, Griffith JL, Townsend PA (2009) Detection of flooding responses at the river basin scale enhanced by land use change. Water Resour Res 45(8). doi:10.1029/2008WR007594

McDonald A, Lane SN, Haycock NE, Chalk EA (2004) Rivers of dreams: on the gulf between theoretical and practical aspects of an upland river restoration. Trans Inst Br Geogr 29(3):257-281

McLain RG, Lee RJ (1996) Adaptive management: promises and pitfalls. Environ Manag 20(4):437-448

Medd W, Marvin S (2008) Making water work: Intermediating between regional strategy and local practice. Environ Plan D Soc Space 26(2):280

National Audit Office (2014) Strategic flood risk management HC 780 Session 2014-2015, 5 November (2014)

Newman D (2006) The lines that continue to separate us: borders in our borderless' world. Prog Human Geograp 30(2):143-161

Newson M (2008) Land, water and development: sustainable and adaptive management of rivers. Routledge, London

Newson M, Large AR (2006) 'Natural' rivers 'hydromorphological quality' and river restoration: a challenging new agenda for applied fluvial geomorphology. Earth Surf Process Land 31(13):1606-1624

Nicholson AR, Wilkinson ME, O'Donnell GM, Quinn PF (2012) Runoff attenuation features: a sustainable flood mitigation strategy in the Belford catchment, UK. Area 44(4):463-469

Nowotny H, Scott P, Gibbons M (2001) Re-thinking science: knowledge and the public in an age of uncertainty. Polity, Cambridge, p 12

Nutley S, Walter I, Davies HT (2003) From knowing to doing a framework for understanding the evidenceinto-practice agenda. Evaluation 9(2):125-148

O'Connell PE, Ewen J, O’Donnell G, Quinn P (2007) Is there a link between agricultural land-use management and flooding? Hydrol Earth Syst Sci 11(1):96-107

Ostrom E (2009) Understanding institutional diversity. Princeton University Press, Princeton

Ostrom E, Gardner R, Walker J, Rules G (1994) Common-pool resources. Ann Arbor University of Michigan Press, Ann Arbor

Pahl-Wostl C (2006) The importance of social learning in restoring the multifunctionality of rivers and floodplains. Ecol Soc 11(1):10 
Pahl-Wostl C, Craps M, Dewulf A, Mostert E, Tabara D, Taillieu T (2007) Social learning and water resources management. Ecol Soc 12(2):5

Parrot A, Brooks W, Harmar O, Pygott K (2009) Role of rural land use management in flood and coastal risk management. J Flood Risk Manag 2(4):272-284

Pattison I, Lane SN (2012) The link between land-use management and fluvial flood risk A chaotic conception? Prog Phys Geogr 36(1):72-92

Penning-Rowsell EC, Priest S, Johnson C (2014) The evolution of UK flood insurance: incremental change over six decades. Int J Water Resour Dev 30(4):694-713

Pitt M (2008) Learning lessons from the 2007 floods. London Cabinet Office, London

Polasky S, Carpenter SR, Folke C, Keeler B (2011) Decision-making under great uncertainty: environmental management in an era of global change. Trends Ecol Evol 26(8):398-404

Raadgever GT, Mostert E, van de Giesen NC et al (2008) Identification of stakeholder perspectives on future flood management in the Rhine basin using Q methodology. Hydrol Earth Syst Sci 12:1097

Robinson WI (2012) Global capitalism theory and the emergence of transnational elites. Crit Sociol 38(3):349-363

Robson AJ (2002) Evidence for trends in UK flooding. Philos Trans R Soc Lond Ser A Math Phys Eng Sci 360(1796):1327-1343

Rouillard JJ, Ball T, Heal KV, Reeves AD (2015) Policy implementation of catchment-scale flood risk management: learning from Scotland and England. Environ Sci Policy 50:155-165

Sadoff CW, Grey D (2002) Beyond the river: the benefits of cooperation on international rivers. Water Policy 4(5):389-403

SAIFF (2011) The Scottish Advisory and Implementation Forum for Flooding

Salman SM (2000) International rivers as boundaries: the dispute over Kasikili/Sedudu island and the decision of the International Court of Justice. Water Int 25(4):580-585

Savory A, Savory A (1988) Holistic resource management (No. 333.7 S2H6).

Straatsma MW, Baptist MJ (2008) Floodplain roughness parameterization using airborne laser scanning and spectral remote sensing. Remote Sens Environ 112(3):1062-1080

Straatsma MW, de Nooij RJ (2010) Evolution of river management: up to integrated and beyond? Nat Culture 5(1):99-115

Tobin GA (1995) The levee love affair: a stormy relationship? J Am Water Resour As 31(3):359-367

UNISDR (2013) Global Assessment Report on Disaster Risk Reduction from Shared Risk to Shared Value: The Business Case for Disaster Risk Reduction United Nations

Werritty A (2006) Sustainable flood management: Oxymoron or new paradigm? Area 38(1):16-23

Werritty A et al (2010) Integrated catchment science: from rhetoric to reality in Scottish HELP Basin' BHS International Hydrology Conference Newcastle 2010

Werritty A, Chatterton J (2004) Future flooding Scotland. Department of Trade and Industry

Wescoat JL, White GF (2003) Water for life: water management and environmental policy. Cambridge University Press, Cambridge

Westmacott S (2001) Developing decision support systems for integrated coastal management in the tropics: Is the ICM decision-making environment too complex for the development of a useable and useful DSS? J Environ Manag 62(1):55-74

Whatmore S (2002) Hybrid geographies: natures cultures spaces. Sage, California

Wiering MA, Arts BJM (2006) Discursive shifts in Dutch river management: 'deep' institutional change or adaptation strategy? In: Living rivers: trends and challenges in science and management. Springer, Dordrecht, pp 327-338

Wiering M, Verwijmeren J, Lulofs K, Feld C (2010) Experiences in regional cross border co-operation in river management comparing three cases at the Dutch-German Border. Water Resour Manag 24(11):2647-2672

Wilby RL, Beven KJ, Reynard NS (2008) Climate change and fluvial flood risk in the UK: More of the same? Hydrol Process 22(14):2511-2523

Yanow D (1996) How does a policy mean? Interpreting policy and organizational actions. Georgetown University Press, Washington, DC 